Badari et al., Reac. Kinet. Mech. Cat. 115 (2015) 217-230.

\title{
Catalytic hydrodenitrogenation of propionitrile over supported nickel phosphide catalysts as model reaction for transformation of pyrolysis oil obtained from animal by-products
}

Cecília A. Badari ${ }^{1}$, Ferenc Lónyi ${ }^{1, *}$, Sándor Dóbé ${ }^{1}$, Jenő Hancsók ${ }^{2}$, József Valyon ${ }^{1}$

${ }^{1}$ Institute of Materials and Environmental Chemistry, Research Centre for Natural Sciences, Hungarian Academy of Sciences, H-1117 Budapest, Magyar tudósok körútja 2., Hungary

${ }^{2}$ Department of Hydrocarbon and Coal Processing, University of Pannonia, H-8200 Veszprém, Egyetem u. 10., Hungary

*Corresponding author.Tel.: +361382 6864. E-mail address: lonyi.ferenc@ttk.mta.hu (F. Lónyi)

\begin{abstract}
Catalytic hydroconversion of propionitrile $(\mathrm{PN})$ was studied over supported nickel and nickel phosphide catalysts. PN was used as model compound of aliphatic nitriles in pyrolysis oil obtained from animal by-products. Silica gel and Laponite was used as support. The structure and particle size of the supported active phase was characterized by X-ray diffractometry (XRD) and transmission electron microscopy (TEM). Catalytic experiments were carried out using a flow-through tube reactor at temperatures between $200-400{ }^{\circ} \mathrm{C}$, total pressure of 30 bar, and $\mathrm{H}_{2} / \mathrm{PN}$ molar ratio of 10. High-pressure operando Diffuse Reflectance Infrared Fourier Transform Spectroscopic (DRIFTS) experiments were carried out to study the species on the catalyst surface during reaction. Results substantiated that propan-1-imine (PI) is surface intermediate of propylamine (PA), dipropylamine (DPA) and tripropylamine (TPA) formation. Conversion of PN to hydrocarbon and ammonia hardly proceeded below $300{ }^{\circ} \mathrm{C}$ but became dominating reaction between $350-400{ }^{\circ} \mathrm{C}$. Brønsted-acid sites were not required for the reactions. Supported $\mathrm{Ni}_{2} \mathrm{P}$ catalysts catalyzed hydrogenolysis of $\mathrm{C}-\mathrm{N}$ bonds only, whereas also the $\mathrm{C}-\mathrm{C}$ bonds suffered significant cleavage over supported Ni catalyst.
\end{abstract}

Keywords: hydrodenitrogenation; $\mathrm{Ni}_{2} \mathrm{P} / \mathrm{SiO}_{2} ; \mathrm{Ni}_{2} \mathrm{P} /$ Laponite; propionitrile; operando DRIFTS 
Badari et al., Reac. Kinet. Mech. Cat. 115 (2015) 217-230.

\section{Introduction}

Conversion of waste biomass to energy carrier and energy became a key issue worldwide. Both waste materials of plant origin [1] and animal by-products [2], such as meat and bone meal (MBM), are potential liquid fuel resources. Fast pyrolysis converts a large fraction of MBM to pyro-oil, containing about $10 \mathrm{wt} \%$ nitrogen, $5 \mathrm{wt} \%$ oxygen and negligible amount of sulfur in organic compounds [2-4]. The pyro-oil, however, cannot be used directly as liquid fuel, mainly because combustion of N-compounds involves emission of environmentally hazardous nitrogen-oxides. Therefore, from MBM pyro-oil environmentally acceptable liquid fuel can be obtained only by deep denitrogenation of the oil, favorably without extensive cracking of the hydrocarbon moiety of molecules. The nitrogen content of the oil can be removed by catalytic hydrodenitrogenation (HDN), which provide a hydrocarbon product and ammonia. The hydrocarbon product can be used as environmentalfriendly, carbon dioxide neutral fuel, whereas ammonia can be converted to $\mathrm{N}$-fertilizer and recycled to the agriculture.

The feeds of crude oil processing contain mainly aromatic heterocyclic molecules. Numerous studies have been devoted to catalytic heteroatom removal from feedstocks and model compounds by hydroprocessing, including the HDN of organic N-compounds [5-7]. The HDN reaction was found to begin with full saturation of the $\mathrm{N}$-containing aromatic ring and the formation of primary amine by breaking one $\mathrm{C}-\mathrm{N}$ bond. The hydrodenitrogenation of nitriles is introduced also by formation of amines. Because mineral oil fractions usually contain also sulfur-compounds the reactions of HDN and hydrodesulfurization (HDS) proceed together. The N-compounds inhibit HDS reaction. In order to model industrial HDN conditions most studies concern the HDN of model compounds in the presence of sulfur compound in the feed, usually over supported or non-supported transition metal sulfides or phosphides. The ammonia was substantiated to be released from quaternized ammonium compound, formed by protonation of primary amine, on the attack of a nucleophilic $\mathrm{HS}^{-}$or $\mathrm{S}^{-}$ species on the catalyst surface [5].

In contrast to petroleum fractions, the $\mathrm{N}$-compounds in the pyro-oil from animal byproducts are mostly aliphatic nitriles, amines and amides and the oil is virtually free of sulfur [2-4]. Recent studies showed that supported $\mathrm{Ni}_{2} \mathrm{P}$ catalysts had considerable HDN activity also in absence of sulfur [8-11]. With the aim to generate knowledge about the HDN processes of feeds containing aliphatic $\mathrm{N}$-compounds in high concentration and virtually no sulfur we studied the catalytic HDN reaction of simple compounds, representing the Norganic molecules of MBM pyro-oil, over supported $\mathrm{Ni}_{2} \mathrm{P}$ catalysts. In previous studies we 
Badari et al., Reac. Kinet. Mech. Cat. 115 (2015) 217-230.

reported about the $\mathrm{HDN}$ of PA $[12,13]$ over silica supported $\mathrm{Ni}$ and $\mathrm{Ni}_{2} \mathrm{P}$ catalyst. The present work concerns the HDN of PN over the very same catalysts and a less active Laponitesupported $\mathrm{Ni}_{2} \mathrm{P}$ catalyst. The primary objective of the present work was to describe the reaction network of PN HDN including the surface and the reaction intermediates of alkane and ammonia formation.

\section{Experimental}

\subsection{Catalyst preparation}

Nickel phosphide catalysts supported on silica gel (SYLOBEAD B127, Grace Davison; specific surface area $563 \mathrm{~m}^{2} / \mathrm{g}$ ) and synthetic hectorite, called Laponite (Laponite RD, obtained from Rockwood, Ltd., UK, having a composition of $\left[\mathrm{Mg}_{5.34} \mathrm{Li}_{0.66} \mathrm{Si}_{8} \mathrm{O}_{20}(\mathrm{OH})_{4}\right] \mathrm{Na}_{0.66}$, and specific surface area $354 \mathrm{~m}^{2} / \mathrm{g}$ ) were prepared. The silica supported $\mathrm{Ni}_{2} \mathrm{P}$ catalyst was prepared by wet impregnation, followed by calcination and controlled reduction of the nickel phosphide precursor compounds according to refs. [6,7]. The procedure of catalyst preparation and a detailed characterization of the catalysts are given in refs. [12] and [13]. Briefly, an impregnation solution was prepared by dissolving $\left(\mathrm{NH}_{4}\right)_{2} \mathrm{HPO}_{4}$ and $\mathrm{Ni}\left(\mathrm{NO}_{3}\right)_{2}$ in distilled water and having initial P/Ni molar ratio of 2 . The concentration of $\left(\mathrm{NH}_{4}\right)_{2} \mathrm{HPO}_{4}$ and $\mathrm{Ni}\left(\mathrm{NO}_{3}\right)_{2}$ in the solution was 4.6 and $2.3 \mathrm{~mol} / \mathrm{dm}^{3}$, respectively. This solution was then used to impregnate the pre-dried support. The catalyst precursor was obtained by drying and calcinations at $400{ }^{\circ} \mathrm{C}$.

The Laponite supported catalyst was prepared by suspending $10 \mathrm{~g}$ of Laponite in $250 \mathrm{~cm}^{3}$ of above mentioned solution. The concentration of $\left(\mathrm{NH}_{4}\right)_{2} \mathrm{HPO}_{4}$ and $\mathrm{Ni}\left(\mathrm{NO}_{3}\right)_{2}$ in the solution was 0.092 and $0.046 \mathrm{~mol} / \mathrm{dm}^{3}$, respectively. The $\mathrm{pH}$ of the suspension was 2. After adjusting the $\mathrm{pH}$ to about 7 using $\mathrm{NH}_{3}$ solution a green suspension was obtained. It was stirred at room temperature for $1 \mathrm{~h}$ then most of the aqueous phase was removed by decantation. The chemical analysis confirmed that $95.1 \%$ of $\mathrm{Ni}$ introduced remained on the solid after decantation. Finally, solid was dried first at room temperature and then at $120^{\circ} \mathrm{C}$ overnight and then calcined at $400{ }^{\circ} \mathrm{C}$ for $4 \mathrm{~h}$.

Formation of nickel phosphide was effected by treating the samples in $100 \mathrm{~cm}^{3} \mathrm{~min}^{-1} \mathrm{H}_{2}$ flow. The temperature of the sample in the $\mathrm{H}_{2}$ flow was raised at a rate of $2{ }^{\circ} \mathrm{C} \min ^{-1}$ to the final temperature of the reduction treatment. The silica gel and the Laponite supported catalyst precursors were reduced at $650{ }^{\circ} \mathrm{C}$ and $550{ }^{\circ} \mathrm{C}$, respectively, for 3-3 hours. For reduction the lowest temperature was selected where the $\mathrm{Ni}_{2} \mathrm{P}$ phase could form. This 
Badari et al., Reac. Kinet. Mech. Cat. 115 (2015) 217-230.

temperature was determined from the results of temperature-programmed reduction $\left(\mathrm{H}_{2}-\mathrm{TPR}\right)$ and in situ high-temperature XRD measurements. Finally, the samples were cooled to room temperature in He flow $\left(20 \mathrm{~cm}^{3} \mathrm{~min}^{-1}\right)$ and then contacted with a $50 \mathrm{~cm}^{3} \mathrm{~min}^{-1}$ flow of $1.0 \%$ $\mathrm{O}_{2} / \mathrm{He}$ for $4 \mathrm{~h}$. Latter treatment aimed to passivate the pyrophoric $\mathrm{Ni}_{2} \mathrm{P}$ particles by generating phosphate-like surface layer that prevents the bulk of the particle to become oxidized when the sample was exposed to air $[11,14,15]$. When the obtained material was used as catalyst first an activation treatment was applied in $\mathrm{H}_{2}$ flow at $450{ }^{\circ} \mathrm{C}$.

The silica gel and Laponite-supported catalyst samples are designated as $\mathrm{Ni}_{2} \mathrm{P} / \mathrm{SiO}_{2}$ and $\mathrm{Ni}_{2} \mathrm{P} / \mathrm{L}$, respectively.

For comparative purposes silica gel supported $\mathrm{Ni}$ catalyst $\left(\mathrm{Ni} / \mathrm{SiO}_{2}\right)$ was prepared similarly as were the supported $\mathrm{Ni}_{2} \mathrm{P}$ catalysts, but without adding $\left(\mathrm{NH}_{4}\right)_{2} \mathrm{HPO}_{4}$ to the impregnating solution $[12,13]$.

\subsection{Catalyst characterization}

XRD examinations were carried out using a Philips PW 1810/3710 diffractometer equipped with an XRD cell that allowed in situ reduction of the catalyst precursors with hydrogen at selected temperatures. After $\mathrm{H}_{2}$ treatments the XRD patterns were recorded at room temperature applying monochromatized $\mathrm{CuK} \alpha(\lambda=0.15418 \mathrm{~nm})$ radiation $(40 \mathrm{kV}, 35$ $\mathrm{mA}$ ) and a proportional counter. Crystallite sizes were determined from the line broadening using the Scherrer equation.

Temperature-programmed $\mathrm{H}_{2}$ reduction $\left(\mathrm{H}_{2}-\mathrm{TPR}\right)$ measurements were carried out using $\mathrm{U}$-shaped quartz tube reactor having an internal diameter of $6 \mathrm{~mm}$. The reactor was placed in a furnace. The temperature of the furnace was controlled by temperature programmer. The catalyst samples were pre-treated in $\mathrm{N}_{2}$ flow at $400{ }^{\circ} \mathrm{C}$ for $1 \mathrm{~h}$ then cooled to room temperature in nitrogen. The TPR experiment was carried out by changing the $\mathrm{N}_{2}$ flow to a 30 $\mathrm{cm}^{3} \min ^{-1}$ flow of $10 \% \mathrm{H}_{2} / \mathrm{N}_{2}$. The effluent gas was passed through a dry-ice trap and a thermal conductivity detector (TCD). Data were collected and processed by computer.

The specific surface area of the samples was calculated from isotherms of nitrogen adsorption at $77 \mathrm{~K}$ using the BET method. The isotherms were determined by Quantachrome NOVA Automated Gas Sorption Instrument for samples, previously evacuated at $350{ }^{\circ} \mathrm{C}$ for $1 \mathrm{~h}$.

Electron micrographs were determined by a FEI Morgagni 268D type transmission electron microscope to learn about the morphology of the samples. 
Badari et al., Reac. Kinet. Mech. Cat. 115 (2015) 217-230.

\subsection{Catalytic experiments}

The HDN reaction of propionitrile (PN) model compound was studied using highpressure flow-through catalytic microreactor. The reaction was carried out in the temperature range of $200-400{ }^{\circ} \mathrm{C}$ at $1.0 \mathrm{~h}^{-1} \mathrm{WHSV}$ and 30 bar pressure. The $\mathrm{H}_{2} / \mathrm{PN}$ molar ratio was 10 . The composition of the reactor effluent was analyzed by on-line gas chromatograph (Shimadzu GC-2010 Plus) equipped with an Equity-1 fused silica capillary column (Supelco) and a flame ionization detector (FID). Each catalyst samples were tested for about one week. Reaction conditions were systematically varied. Earlier catalytic runs were repeated time by time in order to check catalytic stability. All the catalysts showed stable activity during the time of examination. No coke deposition was perceptible to the eye on the catalysts removed from the reactor. The carbon content of the feed and the products was virtually equal.

\subsection{Operando DRIFT spectroscopic examination of the HDN reaction}

The spectral analysis of the catalyst surface during catalytic HDN of PN was studied using a Nicolet 5PC spectrometer equipped with a COLLECTOR ${ }^{\mathrm{TM}}$ diffuse reflectance mirror system and a flow-through DRIFT spectroscopic reactor cell (Spectra-Tech, Inc.). First the catalyst was treated in situ in the DRIFTS reactor cell in a $30 \mathrm{~cm}^{3} \mathrm{~min}^{-1}$ flow of $\mathrm{H}_{2}$ at $550{ }^{\circ} \mathrm{C}$ for $1 \mathrm{~h}$ in order to remove the passivating phosphate surface layer of the nickel phosphide particles. On each temperature whereon we wanted to run operando catalytic reaction in the DRIFTS cell the spectrum of the catalyst powder was recorded first in $\mathrm{H}_{2}$ flow. The reaction was initiated by switching the $\mathrm{H}_{2}$ flow to a gas saturator containing $\mathrm{PN}$ at $25^{\circ} \mathrm{C}$; thereby the partial pressure of PN was set to 0.1 bar in the hydrogen flow. The total pressure in the reactor cell was varied between atmospheric pressure and 20 bar using a back pressure regulator upstream the cell. Spectra were then taken at temperatures between 100 and $400{ }^{\circ} \mathrm{C}$. The spectrum obtained from the catalyst and the gas mixture in the cell was corrected with the spectrum of the catalyst in $\mathrm{H}_{2}$ at the reaction temperature. The result is a difference spectrum showing the bands of surface species and the absorption bands coming from the vibrationrotation modes of molecules in the gas above the operating catalyst.

\section{Results and discussion}

\subsection{Physical-chemical properties of catalysts}

The chemical composition of the supported $\mathrm{Ni}_{2} \mathrm{P}$ catalysts shows that samples contain significantly higher amount of phosphorous than that corresponding to the $\mathrm{Ni}_{2} \mathrm{P}$ stoichiometry 
(Table 1). The P/Ni molar ratio in the catalyst precursor was 2. A fraction of the phosphorous was retained by the support as surface bound phosphate-like species $[6,11,16]$. These $\mathrm{PO}_{\mathrm{x}}$ species can block some pores of the support and thus may significantly contribute to the loss of specific surface area (Table 1) [16]. Notice that the surface area of the $\mathrm{Ni} / \mathrm{SiO}_{2}$ sample was hardly smaller than that of the support. Since the preparation of the $\mathrm{Ni} / \mathrm{SiO}_{2}$ catalyst did not require the presence of phosphate in the catalyst precursor the surface of the pores remained accessible for adsorption.

The formation of $\mathrm{Ni}_{2} \mathrm{P}$ phase is confirmed by the XRD patterns of the catalysts obtained by in situ reduction of the catalyst precursors (Fig. 1). The XRD reflections at 40.6, 44.6, $47.3,54.2$, and $54.9^{\circ}$ stem from the crystalline $\mathrm{Ni}_{2} \mathrm{P}$ phase of the $\mathrm{Ni}_{2} \mathrm{P} / \mathrm{SiO}_{2}$ and $\mathrm{Ni} 2 \mathrm{P} / \mathrm{L}$ catalysts [10]. On the later Laponite-supported catalyst some nickel-enriched $\mathrm{Ni}_{12} \mathrm{P}_{5}$ phase also appeared beside the $\mathrm{Ni}_{2} \mathrm{P}$ phase (see reflections at 38.05, 41.35 and $49.02^{\circ}$ ). According to TEM examination, the $\mathrm{Ni}_{2} \mathrm{P} / \mathrm{SiO}_{2}$ catalyst contains $\mathrm{Ni}_{2} \mathrm{P}$ particles of $20-60 \mathrm{~nm}$, whereas $100-$ 120-nm size $\mathrm{Ni}_{2} \mathrm{P}$ particles are present in the $\mathrm{Ni}_{2} \mathrm{P} / \mathrm{L}$ sample (Fig. 2). These values correspond well with those calculated from the XRD patterns using the Scherrer equation (Table 1). The $\mathrm{Ni} / \mathrm{SiO}_{2}$ catalyst presents weak reflection lines at $44.5^{\circ}$ and $52.0^{\circ}$ characteristic of $\mathrm{Ni}$ metal particles (Fig. 1). Their calculated average particle size is $11 \mathrm{~nm}$, which is somewhat larger than that measured by TEM $(2-10 \mathrm{~nm})$ due to the fact that particles smaller than about $5 \mathrm{~nm}$ cannot be detected by XRD (Table 1).

\subsection{Catalytic hydroconversion of $P N$}

Both $\mathrm{Ni} / \mathrm{SiO}_{2}$ and $\mathrm{Ni}_{2} \mathrm{P} / \mathrm{SiO}_{2}$ catalysts show high activity in the hydroconversion of $\mathrm{PN}$ at reaction temperature as low as $200{ }^{\circ} \mathrm{C}$ (Fig. 3a,b). At reaction temperatures below about $300{ }^{\circ} \mathrm{C}$ the main reaction products are PA, DPA, TPA, and ammonia. Results imply that under the applied reaction conditions PN is easily hydrogenated to PA, which then can further transform to DPA and TPA products. Formation of these products suggests a similar reaction network than the one, which was put forward earlier for the catalytic hydrogenation of nitriles to amines [17-22]. Formation of amine is generally described to proceed through aldimine intermediate as shown by Eq. (1):

$$
\underset{\text { nitrile }}{\mathrm{R}-\mathrm{C} \equiv \mathrm{N}} \stackrel{+\mathrm{H}_{2}}{\rightarrow} \underset{\text { aldimine }}{\mathrm{R}-\mathrm{CH}=\mathrm{NH}} \stackrel{+\mathrm{H}_{2}}{\rightarrow} \underset{\text { primary amine }}{\mathrm{R}-\mathrm{CH}_{2}-\mathrm{NH}_{2}}
$$

Secondary amine is formed from the addition of primary amine to the aldimine intermediate, leading to the formation of 1-aminodialkylamine. Elimination of ammonia from latter species 
Badari et al., Reac. Kinet. Mech. Cat. 115 (2015) 217-230.

leads to the formation of alkylideneamine intermediate, which is then hydrogenated to secondary amine product as shown by Eq. (2):

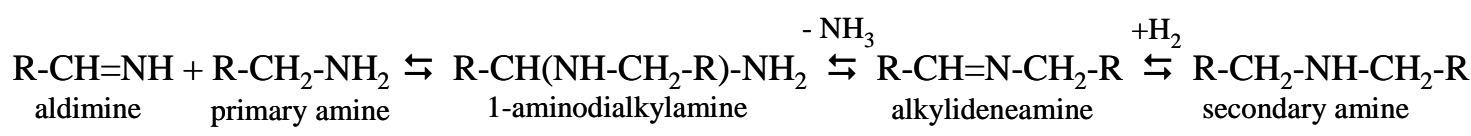

Formation of tertiary amine takes place on a similar pathway except that the aldimine intermediate reacts with secondary amine and the reaction proceeds via 1-aminotrialkylamine and enamine intermediates. It must be noted that former mechanism does not necessarily involve heterogeneous catalysis [22]. Although the product distribution, reaction intermediates, and surface species observed during the catalytic hydrogenation clearly support the above mechanism, some details, including the role of acidic and metallic sites in the reaction, are still matter of debate $[17,18,20,21]$.

While the $\mathrm{C} \equiv \mathrm{N}$ bond of $\mathrm{PN}$ was quickly hydrogenated leading to the formation of amine group, the subsequent $\mathrm{C}-\mathrm{N}$ bond breaking in the amine resulting in hydrocarbon and ammonia products hardly proceeded below $300^{\circ} \mathrm{C}$ (Fig. 3a,b). The C-N bond hydrogenolysis became dominating reaction at temperatures higher than about $300{ }^{\circ} \mathrm{C}$. Above $300{ }^{\circ} \mathrm{C}$ the reaction over $\mathrm{Ni}_{2} \mathrm{P} / \mathrm{SiO}_{2}$ catalyst provides ammonia and propane as major products and some $\mathrm{C}_{4}-\mathrm{C}_{6}$ hydrocarbon by-products. In contrast, over $\mathrm{Ni} / \mathrm{SiO}_{2}$ catalyst, beside ammonia, methane and ethane were formed in significant amounts. Latter products show that the $\mathrm{Ni} / \mathrm{SiO}_{2}$ catalyst is active not only in the $\mathrm{C}-\mathrm{N}$ bond but also in the $\mathrm{C}-\mathrm{C}$ bond hydrogenolysis reaction.

Above about $300{ }^{\circ} \mathrm{C}$ the $\mathrm{Ni}_{2} \mathrm{P} / \mathrm{L}$ catalyst shows similar catalytic properties in the HDN reaction than the above characterized silica supported catalysts. However, at temperatures lower than $300{ }^{\circ} \mathrm{C}$ the activity depends on the applied support. The hydrogenation and disproportionation activity of the $\mathrm{Ni}_{2} \mathrm{P} / \mathrm{L}$ catalyst, resulting in the formation of primary, secondary, and tertiary amines, is significantly lower than those of the two silica supported catalysts (Fig. 3c). A further difference is the TPA/DPA ratio in the reaction product. The TPA formation is more favored over the Laponite-supported catalyst (Fig. 3). These results suggest that the particle size of the $\mathrm{Ni}_{2} \mathrm{P}$ active phase and/or the properties of the support can play important role in the hydrogenation and transamination reactions. Nevertheless, nearly full conversion of PN to hydrocarbon and ammonia was attained over each catalyst at about $400{ }^{\circ} \mathrm{C}$ (Fig. 3). 
Badari et al., Reac. Kinet. Mech. Cat. 115 (2015) 217-230.

\subsection{Operando DRIFT spectroscopic investigation}

Difference infrared spectra obtained by subtracting the spectrum of the catalyst from the spectrum of the catalyst contacting with the $\mathrm{PN} / \mathrm{H}_{2}$ reactant mixture under the indicated reaction conditions are presented in Figs. 4-6. The appearance of negative band in the difference spectrum indicates consumption or perturbation of surface species assigned to the band by adsorption interaction with reactant or product molecules, whereas positive bands come from new surface species.

In the $v(\mathrm{OH})$ region negative bands appeared at 3740 and $\sim 3500 \mathrm{~cm}^{-1}$ (broad, not labeled band) over the $\mathrm{Ni} / \mathrm{SiO}_{2}$ catalyst (Fig. 4a). These bands can be assigned to free and associated silanol groups, respectively. The bands are negative, indicating that the $\mathrm{Si}-\mathrm{OH}$ groups are involved in H-bonding interaction with some molecules of the reaction mixture [23]. The $\mathrm{H}-$ bonding generates strong broad $v_{\mathrm{OH}}$ bands shifted to the $3500-2800 \mathrm{~cm}^{-1}$ spectral region. In this region the baseline shows significant raise in the direction of lower wavenumbers that might come from the red-shifted $v(\mathrm{OH})$ bands, which are broad, overlapping, and unresolved. The strong overlapping absorption bands around $3000 \mathrm{~cm}^{-1}$ can be attributed to asymmetric and symmetric $v\left(\mathrm{CH}_{3}\right)$ and $v\left(\mathrm{CH}_{2}\right)$ stretching vibrations of methyl and methylene groups of adsorbed species (Fig. 4a). The bands of the corresponding deformation vibrations appear at $1470 \mathrm{~cm}^{-1}\left(\delta_{\mathrm{as}}\left(\mathrm{CH}_{3}\right), \delta\left(\mathrm{CH}_{2}\right)\right)$ and $1390 \mathrm{~cm}^{-1}\left(\delta_{\mathrm{s}}\left(\mathrm{CH}_{3}\right), \omega\left(\mathrm{CH}_{2}\right)\right)($ Fig. 4b) [24-26]. A weak absorption band is discernible at $2250 \mathrm{~cm}^{-1}$, which is attributed to the $v(C \equiv N)$ vibration of $P N$. The $\delta\left(\mathrm{CH}_{2}\right)$ vibration of methylene group neighboring $\mathrm{C} \equiv \mathrm{N}$ group appears at $1430 \mathrm{~cm}^{-1}$ $[22,27]$. The low intensity of latter two bands suggests that quick transformation of PN proceeds already at $100{ }^{\circ} \mathrm{C}$ over the $\mathrm{Ni} / \mathrm{SiO}_{2}$ catalyst, which is in accordance with the results of the reactor tests (Fig. 3a). The formation of PA is clearly indicated by the appearance of the absorption bands at 3360 and $3300 \mathrm{~cm}^{-1}$, assigned to $v_{\mathrm{as}}\left(\mathrm{NH}_{2}\right)$ and $v_{\mathrm{s}}\left(\mathrm{NH}_{2}\right)$ vibrations of the amine group of adsorbed primary amine together with the corresponding $\beta\left(\mathrm{NH}_{2}\right)$ vibration at $1595 \mathrm{~cm}^{-1}$ and $v(\mathrm{CN}(\mathrm{H}))$ vibration at $1085 \mathrm{~cm}^{-1}$ (Fig. 4) [24,26]. The bands of gas phase ammonia also appear at 965-930 (inversion doubling), 1626 and $3334 \mathrm{~cm}^{-1}$ with rotational side bands [25]. Gas phase ammonia may appear as product of either $\mathrm{C}-\mathrm{N}$ bond hydrogenolysis or transamination reactions (Eq. 2). Because reaction study of section 3.2 showed that propane formation was negligible at low temperatures $\left(<300{ }^{\circ} \mathrm{C}\right)$ and the major reaction product was DPA (Fig. 3a), the ammonia must have come mostly from disproportionation reaction. Formation of DPA is also confirmed by the appearance of the bands at $2810 \mathrm{~cm}^{-1}$ and $1135 \mathrm{~cm}^{-1}$, which bands correspond to vibration frequencies of 
Badari et al., Reac. Kinet. Mech. Cat. 115 (2015) 217-230.

symmetric $\mathrm{CH}_{2}(\mathrm{~N})$ and $\mathrm{C}-\mathrm{N}(\mathrm{C})$ stretching vibrations in DPA molecules, respectively [24,25]. At $300{ }^{\circ} \mathrm{C}$ and above the $\mathrm{Ni} / \mathrm{SiO}_{2}$ catalyst started to convert DPA to gas phase hydrocarbon and ammonia as shown by the sharp vibration band of gas phase $\mathrm{CH}_{4}$ at $3015 \mathrm{~cm}^{-1}$ and its rotational side bands in the spectrum (Fig. 4a, spectra e-g). These spectral changes are in full agreement with the results of the reaction study (Section 3.2.) and suggest that the HDN reaction of PN proceeds via PA and DPA intermediates on the supported Ni catalyst. However, the $\mathrm{Ni} / \mathrm{SiO}_{2}$ catalyst shows high activity in the hydrogenolysis of the $\mathrm{C}-\mathrm{C}$ bonds leading to fragmentation of the hydrocarbon chain.

Similar spectra could be observed over $\mathrm{Ni}_{2} \mathrm{P} / \mathrm{SiO}_{2}$ than over the above discussed $\mathrm{Ni} / \mathrm{SiO}_{2}$ catalyst (c.f. Fig. 5 and Fig. 4), except that the characteristic bands for PN ( $(\mathrm{C} \equiv N)$ at 2250 $\mathrm{cm}^{-1}$ and $\left.\delta\left(\mathrm{CH}_{2}\right) 1430 \mathrm{~cm}^{-1}\right)$ appeared with higher intensity in the low-temperature range $\left(<250{ }^{\circ} \mathrm{C}\right)$ (Fig. 5). The higher intensity of the bands assigned to PN and thus the higher surface concentration of the reactant is due to the lower hydrogenation activity of $\mathrm{Ni}_{2} \mathrm{P} / \mathrm{SiO}_{2}$ catalyst relatively to that of the silica supported Ni catalyst as shown by the catalytic results (c.f. Fig. 3a and 3b). An additional pair of bands could be observed at 2530 and $2400 \mathrm{~cm}^{-1}$ not obtained from the reaction over $\mathrm{Ni} / \mathrm{SiO}_{2}$. Note that the hydrogen phosphate species attached to silica support of the $\mathrm{Ni}_{2} \mathrm{P} / \mathrm{SiO}_{2}$ catalyst have Brønsted acidity $[28,29]$. The surface phosphate species are formed during catalyst preparation in the reaction of silica hydroxyl groups and the phosphorus source $\left(\mathrm{NH}_{4}\right)_{2} \mathrm{HPO}_{4}$ applied in large stoichiometric excess to the nickel source [30]. The $v(\mathrm{OH}(\mathrm{P}))$ band appears at $3665 \mathrm{~cm}^{-1}$ (Fig. 5a). Because no bands were obtained at 2530 and $2400 \mathrm{~cm}^{-1}$ from adsorption of alkylamine over silica supports not having Brønsted acidity [31], it seems most probable that these bands stem from $v_{\mathrm{as}}\left(\mathrm{NH}_{2}{ }^{+}\right)$and $v_{\mathrm{s}}\left(\mathrm{NH}_{2}{ }^{+}\right)$ vibrations of protonated surface-bound DPA $\left(\mathrm{DPAH}^{+}\right)[24,25]$. Note that formation of $\mathrm{DPAH}^{+}$confirms the presence of relatively strong Brønsted-acid sites in our $\mathrm{Ni}_{2} \mathrm{P} / \mathrm{SiO}_{2}$ catalyst $[28,29]$, which are able to protonate strong N-bases. Interestingly, no obvious sign for the formation of protonated PA $\left(\mathrm{PAH}^{+}\right)$is discernible in the spectra, although PA also appears among the gas phase reaction products. Our earlier study on the hydroconversion of PA showed that the $\delta_{\mathrm{s}}\left(\mathrm{NH}_{3}{ }^{+}\right)$band of $\mathrm{PAH}^{+}$should appear at $1530 \mathrm{~cm}^{-1}$ [13]. Note however, that in the present study PA is formed by the hydrogenation of PN and it is intermediate of DPA formation. Latter product appears in a significantly higher concentration in the product mixture than PA (Fig. 3b) and also have a higher proton affinity than PA (DPA: $962.3 \mathrm{~kJ} / \mathrm{mol}$, PA: $917.8 \mathrm{~kJ} / \mathrm{mol}$ [32]), which explain that $\mathrm{DPAH}^{+}$occupy most of the acid sites and appears as dominating protonated surface species. Nevertheless, the concentration of protonated DPA hardly changes at up to about $300{ }^{\circ} \mathrm{C}$ reaction temperature, indicating that these species are 
Badari et al., Reac. Kinet. Mech. Cat. 115 (2015) 217-230.

strongly bound and highly stable spectator species (Fig. 5a, spectra a-e). Above $300{ }^{\circ} \mathrm{C}$ DPA is consumed with the simultaneous formation of gas phase hydrocarbon and ammonia over the $\mathrm{Ni}_{2} \mathrm{P} / \mathrm{SiO}_{2}$ catalyst (Fig. 5a, spectra e-g); however, methane does not appear as product suggesting that, in contrast to nickel, the $\mathrm{Ni}_{2} \mathrm{P}$ is virtually inactive in the hydrogenolysis of the C-C bonds. Thus, catalytic fragmentation of the hydrocarbon chain could be avoided.

It is important to note that neither propane-1-imine, nor N-propylpropaneimine intermediate (expected according to Eqs. (1) and (2)) could be identified in the spectra collected over $\mathrm{Ni} / \mathrm{SiO}_{2}$ or $\mathrm{Ni}_{2} \mathrm{P} / \mathrm{SiO}_{2}$ catalyst. The $\mathrm{C}=\mathrm{N}$ group in these intermediates should give a characteristic $v(\mathrm{C}=\mathrm{N})$ vibration around $1690-1630 \mathrm{~cm}^{-1}[22,24,25]$. The lack of evidence for their presence on the catalyst surface may suggest that the hydrogenation of the imine intermediates and the addition reaction of the intermediate propylamine to intermediate propane-1-imine are quick under the applied reaction conditions over these catalysts. The rapid consumption of the reaction intermediates imines could result in their very low surface concentration that might prevent their detection. Interestingly, the formation of reaction intermediate containing $\mathrm{C}=\mathrm{N}$ group is obvious over $\mathrm{Ni}_{2} \mathrm{P} / \mathrm{L}$ catalyst as indicated by the absorption band at $1660 \mathrm{~cm}^{-1}$ (Fig. 6b). Latter band gradually develops, while the characteristic band of $\mathrm{PN}$ at $2250 \mathrm{~cm}^{-1}$ decreases at elevated reaction temperatures. Its intensity goes trough a maximum together with the intensity of the band at $2810 \mathrm{~cm}^{-1}$ band of DPA. The $\mathrm{C}=\mathrm{N}$ vibration may belong to propane-1-imine and/or N-propylpropaneimine intermediate as suggested by Eqs. (1) and (2). The present results do not allow us to clearly distinguish these imine intermediates of DPA formation by their $\mathrm{C}=\mathrm{N}$ vibration band. Similar band was observed $1671 \mathrm{~cm}^{-1}$ during the hydrogenenation of butyronitrile over Raney-Ni catalysts and was assigned to N-butylbutaneimine [33]. The assignment of latter study substantiates that absorption band at $1660 \mathrm{~cm}^{-1}$ (Fig. 6b) might belong mainly to the $\mathrm{N}$-propylpropaneimine intermediate. The accumulation of intermediates on the surface of $\mathrm{Ni}_{2} \mathrm{P} / \mathrm{L}$ catalyst is less understood at present. The lack of protonated species strongly suggests that in contrast to the silica support Brønsted-acid sites with considerable strength were not formed on the Laponite support. Thus the accumulation of imine intermediates might be related to the different adsorption sites of the Laponite support, which can hold such unsaturated intermediates more strongly than those of the silica support and, thereby, prevent their quick transformation. The possible adsorption sites on Laponite can be identified as $\mathrm{SiOH}\left(v_{\mathrm{OH}}\right.$ vibration at $\left.3732 \mathrm{~cm}^{-1}\right), \mathrm{Mg}_{2} \mathrm{LiOH}\left(v_{\mathrm{OH}}\right.$ vibration at $\left.\sim 3705 \mathrm{~cm}^{-1}\right)$ and $\mathrm{Mg}_{3} \mathrm{OH}\left(v_{\mathrm{OH}}\right.$ vibration at $3675 \mathrm{~cm}^{-1}$ ) [34], the latter two of which are not present on the silica support and probably responsible for the stronger adsorption of the intermediates. These adsorption sites 
Badari et al., Reac. Kinet. Mech. Cat. 115 (2015) 217-230.

are most probably lead to the basic character of Laponite surface [35]. The higher surface concentration of unsaturated intermediates is related to their longer lifetime over $\mathrm{Ni}_{2} \mathrm{P} / \mathrm{L}$ catalyst relatively to the silica supported catalysts, which probably also explains the higher relative concentration of tertiary amine to lower amines. Note that TPA can be formed in reaction between propane-1-imine intermediate and DPA. The above discussed spectral features clearly suggest that formation of higher amines most probably proceeds on the same reaction routes as suggested before on different supported metal catalysts [17-21].

Although the overall mechanism shown by Eqs. (1) and (2) is widely accepted, some details of the catalytic hydrogenation of nitriles, especially the role of acidic and metallic sites in the reaction, are still matter of debate. Verhaak et al. [17] suggested bi-functional mechanism, in which the hydrogenation reactions take place on the active metal component, while the acid function of the support is responsible for the condensation and ammonia elimination reactions leading to secondary and tertiary amines. Later studies suggested a similar bi-functional mechanism, in which DPA and TPA products are formed by condensation reaction between the imine and amine species adsorbed on metallic centers and acid sites of the support, respectively; however, it was also shown that in the absence of acid sites the reaction may proceed just on the metal sites $[18,21,22]$. Sachtler et al. concluded that the selectivity to different amines is predominantly determined by the chemical nature of the metal, irrespective of the nature of the support including its acidity [20]. Our results revealed that the hydrogenation of PN to PA and the consecutive disproportionation reaction of PA leading to the formation of higher amines at temperatures below $300{ }^{\circ} \mathrm{C}$ follows the same reaction path on $\mathrm{Ni} / \mathrm{SiO}_{2}$ and $\mathrm{Ni}_{2} \mathrm{P} / \mathrm{SiO}_{2}$ catalyst. Since former catalyst does not, whereas the latter catalyst does contain Brønsted acid sites, we can conclude that Brønsted acid sites are not required for the reaction. Over the Brønsted acid sites of catalyst $\mathrm{Ni}_{2} \mathrm{P} / \mathrm{SiO}_{2}$ strongly bound protonated DPA species were formed, which, as mentioned above, are most likely spectator species.

\section{Conclusions}

Propionitrile is quickly hydrogenated to propylamine already below $200{ }^{\circ} \mathrm{C}$ over silica supported $\mathrm{Ni}$ and $\mathrm{Ni}_{2} \mathrm{P}$ catalysts. The propylamine intermediate is then denitrogenated mainly in disproportionation reactions through propane-1-imine, 1-aminodipropylamine, and $\mathrm{N}$ propylpropaneimine intermediates giving ammonia, and secondary and tertiary amines. Above about $300{ }^{\circ} \mathrm{C}$ the primary, secondary and tertiary amines become intermediates of 
Badari et al., Reac. Kinet. Mech. Cat. 115 (2015) 217-230.

alkane and ammonia formation. Silica supported Ni catalyst initiate not only the hydrogenolysis of the $\mathrm{C}-\mathrm{N}$ bonds, but also that of the $\mathrm{C}-\mathrm{C}$ bonds resulting in significant amount of methane and ethane products. Brønsted-acid sites are required neither for the disproportionation reactions nor for the ammonia elimination from the reaction intermediates. Protonated dipropylamine species formed on the Brønsted-acid sites of $\mathrm{Ni}_{2} \mathrm{P}_{/} \mathrm{SiO}_{2}$ catalyst were identified, which are most likely spectator species. The support does not seem to have any contribution to the HDN activity of the catalyst. The expected propane-1-imine and/or Npropylpropaneimine intermediates could not be detected by operando DRIFT spectroscopy over silica supported catalysts probably due to their quick transformation. However, formation of these unsaturated intermediates could be substantiated on the Laponite supported $\mathrm{Ni}_{2} \mathrm{P}$ catalyst, most probably due to the stronger adsorption of imines on the Laponite than on the silica. The stronger adsorption may hinder the transformation of the imines and permit their accumulation on the catalyst surface, which allowed their detection by DRIFT spectroscopy. The surface concentration of the unsaturated intermediate, most probably mainly N-propylpropaneimine, is strongly related to the surface concentration of dipropylamine. Near to $400{ }^{\circ} \mathrm{C}$ the $\mathrm{C}-\mathrm{N}$ hydrogenolysis reaction is the dominating reaction.

\section{Acknowledgement}

Thanks are due to the Hungary-Slovakia Cross-border Co-operation Program (Project registration number: HUSK/1101/1.2.1/0318) for supporting this research. We also acknowledge the financial support of the Hungarian State and the European Union under the TAMOP-4.2.2.A-11/1/KONV-2012-0071 and TAMOP-4.1.1.C-12/1/KONV-20120017. 
Badari et al., Reac. Kinet. Mech. Cat. 115 (2015) 217-230.

Table 1. Characterization of catalysts.

\begin{tabular}{lccccc}
\hline Catalysts & $\mathrm{SSA},{ }^{\mathrm{a}} \mathrm{m}^{2} \mathrm{~g}^{-1}$ & $\mathrm{Ni}, \mathrm{wt} \%$ & $\mathrm{P}, \mathrm{wt} \%$ & $\mathrm{D},{ }^{\mathrm{b}} \mathrm{nm}$ & $\mathrm{D},{ }^{\mathrm{c}} \mathrm{nm}$ \\
\hline $\mathrm{Ni} / \mathrm{SiO}_{2}{ }^{\mathrm{d}}$ & $558(563)$ & 6.76 & - & $2-10$ & 11 \\
$\mathrm{Ni}_{2} \mathrm{P} / \mathrm{SiO}_{2}{ }^{\mathrm{d}}$ & $268(563)$ & 5.04 & 4.11 & $20-60$ & 49 \\
$\mathrm{Ni}_{2} \mathrm{P} / \mathrm{L}$ & $212(354)$ & 5.65 & 3.99 & $100-120$ & 120 \\
\hline
\end{tabular}

${ }^{\text {a }} \mathrm{SSA}=$ specific surface area, determined by the Brunauer-Emmett-Teller (BET) method (specific surface area of the support is given in parentheses). ${ }^{\mathrm{b}}$ Diameter of particles of the active phase observed in the TEM micrograph.$^{c}$ Particle size calculated from XRD by Scherrer equation. ${ }^{\mathrm{d}}$ Results obtained for $\mathrm{Ni} / \mathrm{SiO}_{2}$ and $\mathrm{Ni}_{2} \mathrm{P} / \mathrm{SiO}_{2}$ catalysts were taken from ref. [12]. 
Badari et al., Reac. Kinet. Mech. Cat. 115 (2015) 217-230.

\section{References}

[1] Bulushev DA, Ross JRH (2011) Catal Today 171:1-13

[2] Cascarosa E, Gea G, Arauzo J (2012) Renewable and Sustainable Energy Reviews 16:942-957

[3] Ayllón M, Aznar M, Sánchez JL, Gea G, Arauzo J (2006) Chemical Engineering Journal 121:85-96

[4] Cascarosa E, Fonts I, Mesa JM, Sánchez JL, Arauzo J (2011) Fuel Processing Technology 92:1954-1962

[5] Furimsky E, Massoth FE (2005) Catal Rev 47:297-489

[6] Oyama ST, Wang X, Lee Y-K, Bando K, Requejo FG (2002) J Catal 210:207-217

[7] Gott T, Oyama ST (2009) J Catal 263:359-371

[8] Oyama ST (2003) J Catal 216:343-352

[9] Zuzaniuk V, Prins R (2003) J Catal 219:85-96

[10] Oyama ST, LeeY-K (2005) J Phys Chem B 109:2109-2119

[11] Infantes-Molina A, Cecilia JA, Pawelec B, Fierro JLG, Rodríguez-Castellón E, Jiménez-López A (2010) Appl Catal A 390:253-263

[12] Badari AC, Harnos Sz, Lónyi F, Onyestyák Gy, Štolcová M, Kaszonyi A, Valyon J (2015) Catal Commun 58:1-5

[13] Badari CA, Lónyi F, Drotár E, Kaszonyi A, Valyon J (2015) Appl Catal B 164:48-60

[14] Sawhill SJ, Phillips DC, Bussell ME (2003) J Catal 215:208-219

[15] Bui P, Cecilia JA, Oyama ST, Takagaki A, Infantes-Molina A, Zhao H, Li D, Rodríguez-Castellón E, López AJ (2012) J Catal 294:184-198

[16] Korányi TI, Vít Z, Poduval DG, Ryoo R, Kim HS, Hensen EJM (2008) J Catal 253:119-131

[17] Verhaak MJFM, Van Dillen AJ, Geus JW (1994) Catal Lett 26:37-53

[18] Cabello FM, Tichit D, Coq B, Vaccari A, Dung NT (1997) J Catal 167:142-152

[19] Dung NT, Tichit D, Chiche BH, Coq B (1998) Appl Catal A 169:179-187

[20] Huang Y, Sachtler WMH (1999) Appl Catal A 182:365-378

[21] Coq B, Tichit D, Ribet S (2000) J Catal 189:117-128

[22] Ortiz-Hernandez I, Williams CT (2007) Langmuir 23:3172-3178

[23] Pazé C, Bordiga S, Lamberti C, Salvalaggio M, Zecchina A, Bellussi G (1997) J Phys Chem B 101:47404751

[24] Larkin P (2011) Infrared and Raman Spectroscopy; Principles and Spectral Interpretation. Elsevier Inc, pp. 73-115

[25] Holly S, Sohár P (1968) Infrared Spectroscopy, Müszaki Könyvkiadó, Budapest, pp. 45-114 (in Hungarian)

[26] Schenkel R, Olindo R, Kornatowski J, Lercher JA (2006) Appl Catal A 307:108-117

[27] Growder GA (1986) Spectrochimica Acta 42A(10):1229-1231

[28] Busca G, Ramis G, Lorenzelli V, Rossi PF, Ginestra AL, Patrono P (1989) Langmuir 5:911-916

[29] Ramis G, Rossi PF, Busca G, Lorenzelli V, Ginestra AL, Patrono P (1989) Langmuir 5:917-923

[30] Sawhill SJ, Layman KA, Van Wyk DR, Engelhard MH, Wang C, Bussell ME (2005) J Catal 231:300-313

[31] Morimoto T, Imai J, Nagao M (1974) J Phys Chem 78:704-708

[32] Hunter EP, Lias SG (1998) J Phys Chem Ref Data 27:413-656

[33] Chojecki A (2004) Selective Hydrogenation of Butyronitrile over Raney-Metals. D.Sc. Dissertaion, Technischen Universität München, pp. 74

[34] Pálkova H, Madejová J, Zimowska M, Serwicka EM (2010) Micropor Mesopor Mater 127:237-244

[35] Varade D, Haraguchi K (2013) Langmuir 29:1977-1984 
Badari et al., Reac. Kinet. Mech. Cat. 115 (2015) 217-230.

\section{Figure captions}

Fig. 1 XRD patterns of $\mathrm{Ni} / \mathrm{SiO}_{2}, \mathrm{Ni}_{2} \mathrm{P} / \mathrm{SiO}_{2}$, and $\mathrm{Ni}_{2} \mathrm{P} / \mathrm{L}$ catalysts samples reduced in $\mathrm{H}_{2}$ at $500{ }^{\circ} \mathrm{C}, 650^{\circ} \mathrm{C}$ and $550{ }^{\circ} \mathrm{C}$, respectively for $3 \mathrm{~h}$

Fig. 2 TEM micrographs of (A) $\mathrm{Ni} / \mathrm{SiO}_{2},(\mathrm{~B}) \mathrm{Ni}_{2} \mathrm{P} / \mathrm{SiO}_{2}$ and (D) $\mathrm{Ni}_{2} \mathrm{P} / \mathrm{L}$ catalysts

Fig. 3 Conversion of PN and yields of products in the hydroconversion of PN over (a) $\mathrm{Ni} / \mathrm{SiO}_{2}$, (b) $\mathrm{Ni}_{2} \mathrm{P} / \mathrm{SiO}_{2}$, and (c) $\mathrm{Ni}_{2} \mathrm{P} / \mathrm{L}$ catalysts as a function of reaction temperature; conversion of PN ( $\square)$ and yield values for the ammonia $(\bigcirc)$, propane $(\triangle)$, PA ( $\square$ ), DPA $(\nabla)$, TPA $(\diamond)$, C1-C2 hydrocarbon $(*)$, and C4-C6 hydrocarbon $(\triangleright)$ products were measured at $\mathrm{H}_{2}$ partial pressure of $27.3 \mathrm{bar}$, PN partial pressure of 2.7 bar and at WHSV of 1 $\mathrm{g}_{\mathrm{PN}} \mathrm{g}_{\mathrm{cat}}{ }^{-1} \mathrm{~h}^{-1}$

Fig. 4 Difference DRIFT spectra obtained from the reaction of $\mathrm{PN} / \mathrm{H}_{2}$ over $\mathrm{Ni} / \mathrm{SiO}_{2}$ catalyst at (a) $100{ }^{\circ} \mathrm{C}$, (b) $150{ }^{\circ} \mathrm{C}$, (c) $200{ }^{\circ} \mathrm{C}$, (d) $250{ }^{\circ} \mathrm{C}$, (e) $300{ }^{\circ} \mathrm{C}$, (f) $350{ }^{\circ} \mathrm{C}$, and (g) $400{ }^{\circ} \mathrm{C}$; hydrogen was passed through a $\mathrm{PN}$-containing saturator, kept at $25^{\circ} \mathrm{C}$, at a flow rate of $30 \mathrm{~cm}^{3} \mathrm{~min}^{-1}$; the partial pressure of PN and the total pressure were 0.1 bar and 20 bar, respectively; each spectrum was obtained by subtracting the spectrum of the catalyst in $\mathrm{H}_{2}$ from the corresponding spectrum of the catalyst and the reacting gas

Fig. 5 Difference DRIFT spectra obtained from the reaction of $\mathrm{PN} / \mathrm{H}_{2}$ over $\mathrm{Ni}_{2} \mathrm{P} / \mathrm{SiO}_{2}$ catalyst at (a) $100{ }^{\circ} \mathrm{C}$, (b) $150{ }^{\circ} \mathrm{C}$, (c) $200{ }^{\circ} \mathrm{C}$, (d) $250{ }^{\circ} \mathrm{C}$, (e) $300{ }^{\circ} \mathrm{C}$, (f) $350{ }^{\circ} \mathrm{C}$, and (g) $400{ }^{\circ} \mathrm{C}$; for further experimental conditions see the legend of Fig. 4

Fig. 6 Difference DRIFT spectra obtained from the reaction of $\mathrm{PN} / \mathrm{H}_{2}$ over $\mathrm{Ni}_{2} \mathrm{P} / \mathrm{L}$ catalyst at (a) $100{ }^{\circ} \mathrm{C}$, (b) $150{ }^{\circ} \mathrm{C}$, (c) $200{ }^{\circ} \mathrm{C}$, (d) $250{ }^{\circ} \mathrm{C}$, (e) $300{ }^{\circ} \mathrm{C}$, (f) $350{ }^{\circ} \mathrm{C}$, and (g) $400{ }^{\circ} \mathrm{C}$; for further experimental conditions see the legend of Fig. 4 
Badari et al., Reac. Kinet. Mech. Cat. 115 (2015) 217-230.

Fig. 1

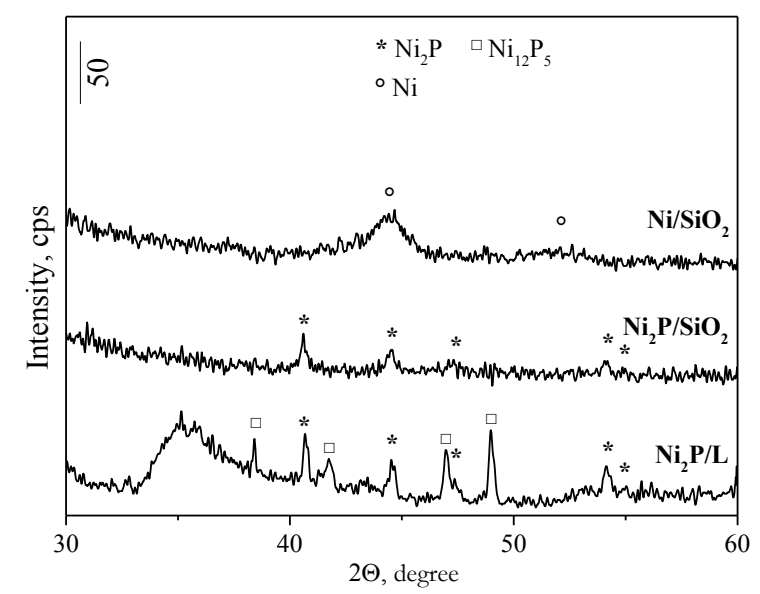

Fig. 2

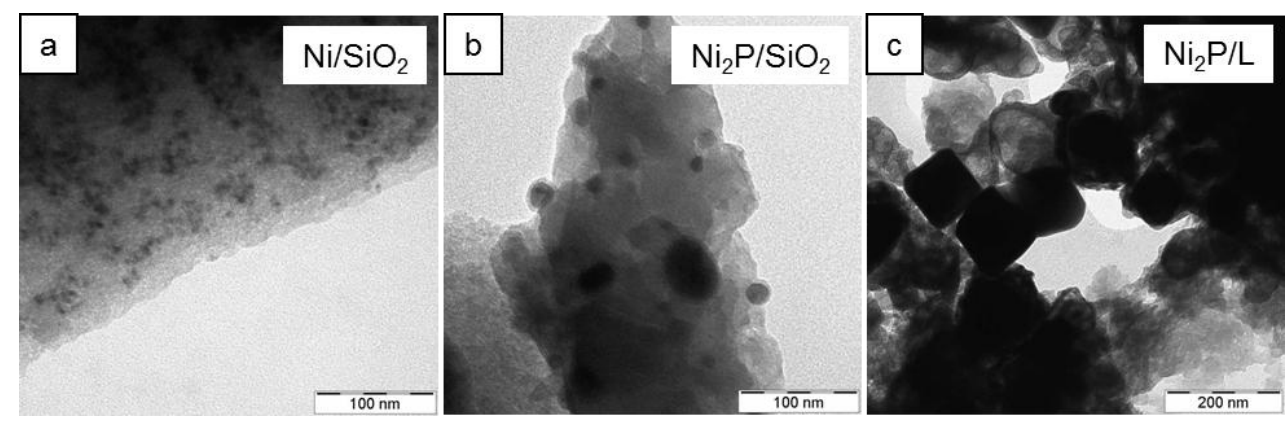


Badari et al., Reac. Kinet. Mech. Cat. 115 (2015) 217-230.

Fig. 3

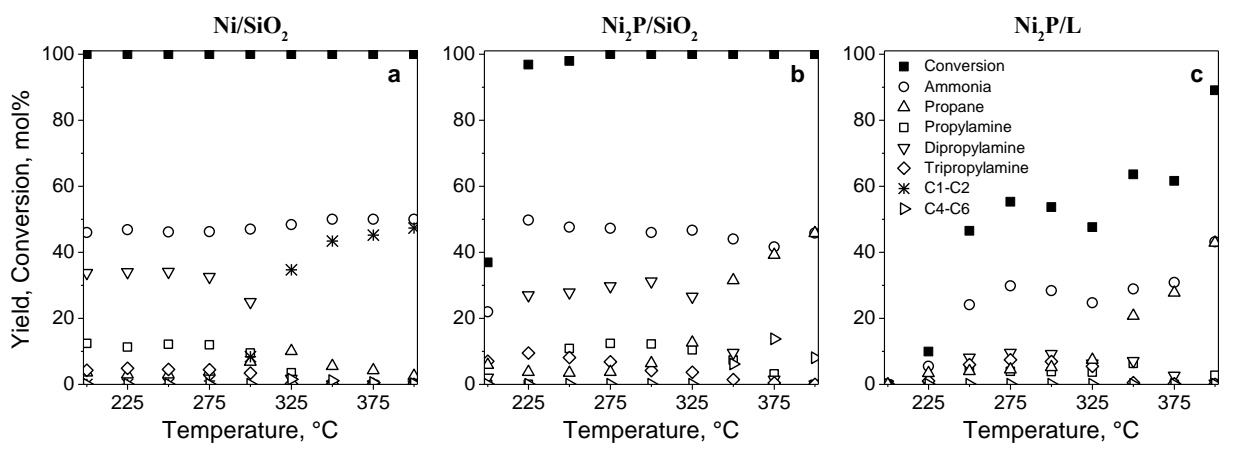

Fig. 4

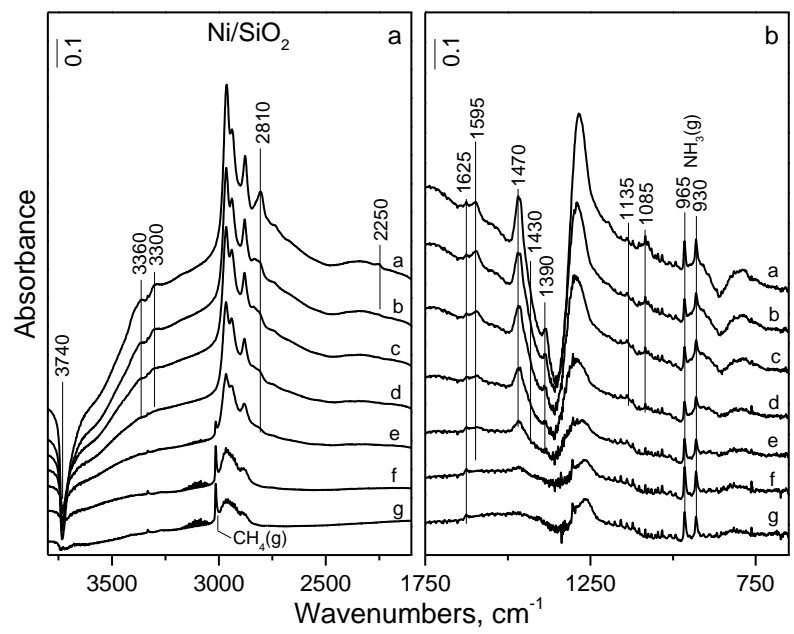


Badari et al., Reac. Kinet. Mech. Cat. 115 (2015) 217-230.

Fig. 5

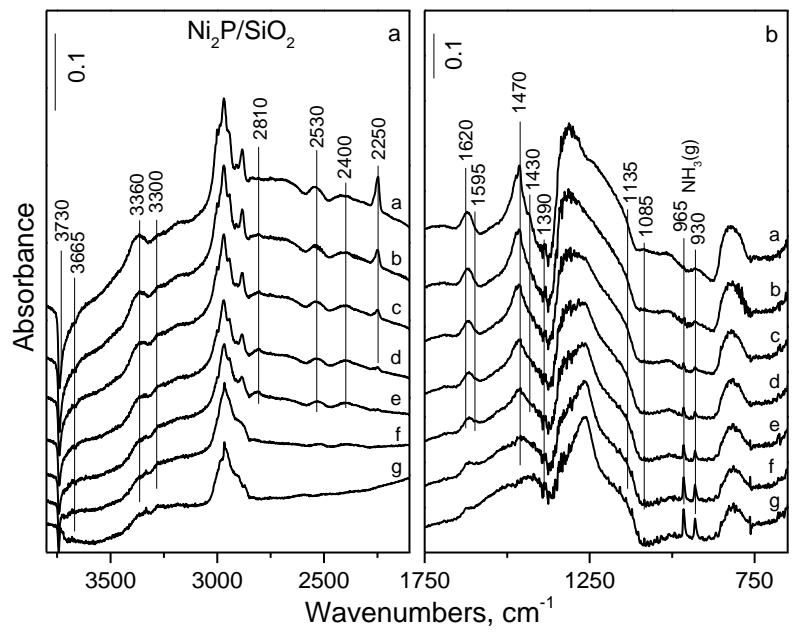

Fig. 6.

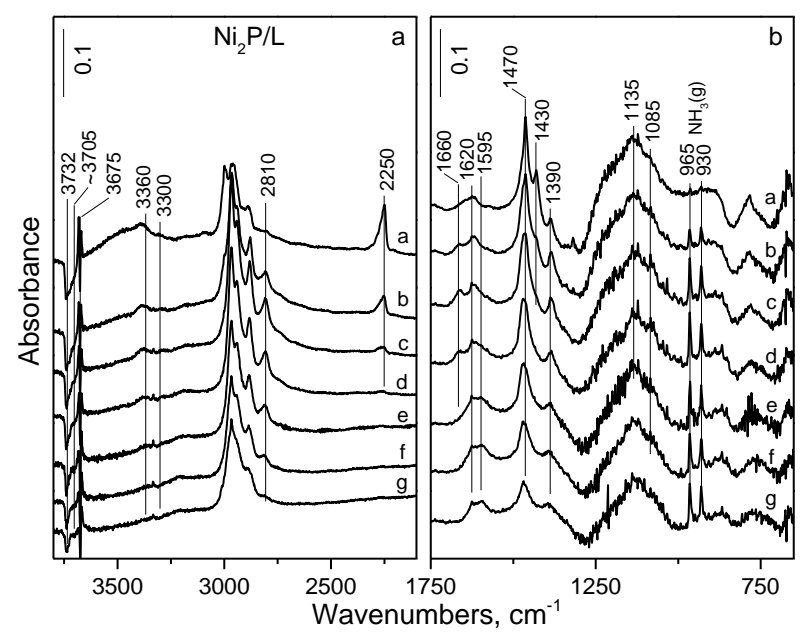

